\title{
Internalization of Islamic Values In Formation of Character Religious Students Pgsd Campus V Unm Parepare
}

\author{
Lukman $^{1}$, Nurjannah ${ }^{2}$ \\ \{1abu_zikran@yahoo.co.id, ${ }^{2}$ nurjannahpare@gmail.com\}
}

${ }^{1,2}$ State University of Makassar, Indonesia

\begin{abstract}
This study aims to (1) describe the process of internalization of the values of the Islamic religion in the formation of the religious character of Student Prodi PGSD Campus V UNM Parepare, (2) describe the factors supporting and inhibiting internalization of the values of the Islamic religion in improving the religious character of students Prodi PGSD Campus V UNM Parepare. The object of research is Student of PGSD Campus V UNM Parepare. This type of research is a field research (field research). Data collection methods are used, namely (1) observation, (2) interviews, and (3) documentation. Data were analyzed using descriptive analysis method, ie an analysis of research that is intended to describe a particular factual situation systematically and accurately, which include data reduction, data display and data verification. The results showed that the internalization process of religious values carried in religious programs are: 1. Reading the Qur'an every start lectures, 2. Make the Journal of Worship, 3. Following the SCIENCE program (Intensive study of the Qur'an) supportive factor and inhibiting the formation of a religious character in V UNM Campus Parepare is: a. The supporting factors: 1) factors from within the student psychologically support the implementation of internalization. 2) External factors: a) Family: family background of students, b) the competence of lecturers in teaching and to provide role models, c) facilities were insufficient for all student activities, d) Society as their place to socialize. b. Inhibiting factors: 1) the inhibiting factors of the students are of themselves due to differences in character, and backgrounds vary. 2) External factors, namely: a) Family: is main factor affecting all the psychological and behavior of students. b) campus environment can be obstacles in the process of internalization of religious values in shaping the character of the students. c) Media information is a requirement that could become an obstacle if one of access. d) Society: People are the limiting factor of the process of internalization of religious values as if they socialize without being able to sort out which is good. c) Media information is a requirement that could become an obstacle if one of access. d) Society: People are the limiting factor of the process of internalization of religious values as if they socialize without being able to sort out which is good. c) Media information is a requirement that could become an obstacle if one of access. d) Society: People are the limiting factor of the process of internalization of religious values as if they socialize without being able to sort out which is good.
\end{abstract}

Keyword: Internalization of Islamic values, the formation of a religious character

\section{Introduction}

God created man as a leader on earth and to accept his mandate to manage and preserve natural resources. Humans are the servants of God who has the obligation to serve and worship Him sincerely. God gives to all mankind the potential to believe in God and practice His teachings. Because of this nature of man dubbed as religious beings. 
Because human beings are created by God aims to profess and practice the teachings of Islam to worship God, as described in the Qur'an letter Adh-Dzaariyat 56:

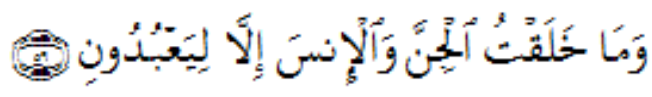

56. and I did not create the jinn and mankind except that they may serve Me. (Ministry of Religious Affairs, 2007: 536)

The text stated that God created man and jinn only to worship him. So that means that people have religious nature to always worship the Creator. A religious nature (basic capabilities) containing the possibility or chance to develop. But in human development is dependent upon the process of education received in the community and all returned to their parents.

Religion explains that humans are creatures that have the potential for good berahlak (taqwa) or bad (fujur). Fujur potential will always exist in human beings as they relate to aspects of instinct, instinctive, or lust, like instinct eat / drink, power and security. If the potential of one's piety is weak, because it does not terkembangkan (through education) (Atjeh, 1968: 23-24).

The soul of religion or religious awareness refers to the spiritual aspects of the individual associated with belief in Allah and it's actualized through worship Him, both the relationship with God (habl minallah) and relationships with humans (habl Minan-nas). Faith in God and actualized in worship is the result of the internalization, the process of recognition, understanding, and awareness of one's self to the values of Islam.

To understand the values of Islam, people certainly need education in the sense of knowing the values of the Islamic religion. So education is a major factor in understanding the meaning of the religion. After knowing the meaning of the values of the Islamic religion is needed in the formation of the human person. Planting these values also in order to reap success in life (hasanah) in the world for students who will then be able to produce (hasanah) in the Hereafter. (Muhaimin, 2005: 6).

Education plays an important role in shaping the human person is good or bad according to the size of the normative. Recognizing this, the government is very serious about dealing with education, because with a good education system is expected to appear the next generation of qualified and able to adapt to living in a society, nation and state.

Since religion was instrumental in the formation of student behavior, so the formation of appropriate students' personal growth and development requires an adequate education. To establish that the student has merit, it is not possible only with the explanation and understanding, but also need to get used to doing the best and expected will have the nature of merit and could avoid a disgraceful nature.

In understanding the values of the Islamic religion, the role of education is very important in the initial process, because education is responsible and determine the direction and purpose of education. With the aim of education for these students to develop the potential that exists in these students to benefit himself and others. As is well known that the character of students is different, because the character of each student is not the same between one another.

Character is interpreted as a way of thinking and behaving that is typical of every individual to live and work, both within the family, community, nation and state. Individuals 
who are of good character is an individual who can make decisions and be ready to account for every result of the decision. (Muchlas Samani, 2011: 410)

In the Islamic view of the same character with morals. Morals in the Islamic view is personality. There are three components of personality that knows (knowledge), attitudes and behavior (Abdul Majid, 2012: 14). Of the third component, if the knowledge, attitude and behavior of the same person then that person personality intact, but if the knowledge, attitudes and behavior of people is not the same between one another yet have a complete personality.

Therefore, in human life certainly require educational values of Islam to develop the character of students in accordance with Islamic law. That is why education is one of the most important factors in developing the potential that exists in one's students. Because without human education certainly can not develop properly. Education can be defined as a process with certain methods so that people can gain knowledge and understanding, and ways of behavior in accordance with the requirements (Shah, 2005: 10).

Religion as stated by Dr. Zakiyah Daradjat also be one of the spiritual needs of people (Grace, 1997: 87). Because humans live in this world needs a sense of security, so people seeking shelter or protection. Supplies and weapons is a human effort to distribute its physical protection needs, while religion is channeling his spiritual protection requirements (Grace, 1997: 83).

The meaning of religious education here is not religious instruction given by the teacher at school, but cultivation of the soul of religion that begins at home, since childhood, with street familiarize the child to the nature and manner in which the good (Daradjat, 1983: 113 ).

Education has an important role in building the child's personality at the same time human intelligence for the better. Therefore, education is constantly being built and developed to produce the next generation of the implementation process is expected. In order to produce students who excel and it is expected that the education process is also constantly evaluated and improved. One effort to improve the quality of education is through character education (Azzet, 2011: 9).

Characters are basic values that build one's personal, well-formed because of the influence of heredity and environmental influences, which distinguishes it from other people, as well as manifested in attitudes and behavior in everyday life (Samani, 2011: 43). Meanwhile, according to Ryan and Bohlin term character contains three main elements, namely know the good (knowing the good), loving kindness (loving the good), and do good (doing the good). (Majid, 2011: 11) That is, an education process that involves cognitive, affective, and psychomotor so noble character can be etched into a habit of the mind, heart, and hands. Character education aims to improve the implementation and results of school education towards achieving the formation of character and noble character of learners as a whole, integrated and balanced, appropriate competency standards. In the history of Islam, the Prophet Muhammad., The last prophet in Islam, also confirmed that the primary mission of educating people is to seek the formation of good character (good character) (Majid, 2011: 30).

Through religious character education learners are expected to be able to independently increase and use knowledge, study and internalize and personalize the character values and noble character so manifest in everyday behavior.

Based on the background of the above problems, the formulation of the problem in this research are as follows:

a. How does the process of internalization of Islamic values in the formation of student religious character PGSD UNM Campus V Parepare?

b. What are the factors supporting and inhibiting internalization of the values of the 
Islamic religion in the formation of student religious character PGSD UNM Campus V Parepare?

\section{Research Methods}

The research approach used in this study is a qualitative approach. Bogdan and Taylor in Moleong defining qualitative methodology as a research procedure that produces descriptive data in the form of words written or spoken of people and behaviors that can be observed. In line with the above opinion, Kirk and Miller define qualitative research as a particular tradition in social science that is fundamentally dependent on the observations to humans in the region as well as in their terminologies (Moleong, 2007: 4).

While this type of research is a field research (field research). The purpose of the research field, including research data obtained from the field, either an oral or a written record of data (documents) (Moleong, 2002: 75).

Which will be the subject of this study is the Student Campus Prodi PGSD V Parepare is located in the Campus V UNM Parepare road Sudirman No. 56 Parepare.

Data collection methods used in this study include:

a. Methods of Observation

An observation method used in this study is a non-participatory observation structured. Non-participatory observation method is the method of observation in which the researcher not involved in the work process or phenomenon which is the object of observation. In this case, the researcher plays an independent and just make the observation of objects symptoms (Sugiyono, 2009: 145). While the intent of the structure is the observation of the object to be observed has been designed and developed systematically (Sugiyono, 2009: 146).

In this study, observational methods used to determine the general picture Prodi PGSD UNM Campus V Parepare, covering geographical, infrastructure and the implementation of the internalization of religious values in the formation of student religious character.

\section{b. Interviews Methods}

Interview method is a method of data collection is done by conducting a conversation with the resources directly (face to face) to obtain information relevant to this study (Arikunto, 1998: 145). The instruments used are not structured interview guide. As for the object of the interview, the students Prodi PGSD UNM Campus V Parepare.

\section{c. Documentation methods}

Documentation method is the method of data collection in the form of written data source, which is a form of writing that is archived or collected. Written data sources can be divided into official documents, books, magazines, archives or personal documents and photos (Sugiyono, 2009: 145). Data will be collected through documentation method includes profiles Prodi PGSD UNM Campus V Parepare.

In the data analysis used descriptive method of analysis, namely an analysis of research that is intended to describe a particular factual situation systematically and accurately (Danim, 2002: 41).There are three stages in the analysis of this data, namely: 1) Data reduction, carried out in the framework of the election and simplification of data. Activities undertaken at this stage is that the data selection and disposal of irrelevant data. The data relevant to the research will be organized to form a set of data that can provide factual information, 2)Presentation of data, carried out in the form of a set of information, in the form of tables, charts, or descriptive narrative, so that the data presented is relatively clear and informative, 3) inference / 
verification of the data, the process of formulating the meaning of the results expressed by the sentences singkat- solid and easy to understand, and is done by repeatedly reviewing the correctness of the inference.

\section{Results And Discussion}

1. Understanding Internalization

In a large dictionary Indonesian internalization interpreted as appreciation, assignment, in-depth mastery that lasted through coaching, guidance, counseling, upgrading, etc. (Department of Education, 1989: 336). Deep appreciation takes place through counseling, upgrading, and so is the confidence and awareness of the truth of doctrine or values embodied in attitudes and behavior.

Internalization is appreciation, deepening, mastery in depth through the target, guidance and so on. Thereby Internalization is a growing process attitudes into one's personal self through coaching, guidance and so forth in order to master the deep ego and to live so that a value can be reflected in the attitudes and behavior in accordance with the standard expected. (Sari: 231)

So deep internalization is a process to live the values of religion, combined with the value of education as a whole whose targets embodied in the personality of students, so that a single character or disposition of learners.

In a psychological sense, internalisation has the meaning unification or incorporation attitudes, standards of behavior, opinions, personality. Freud believed that the superego or moral aspects of personality comes from internalizing the attitudes of parents (Caplin, 1993: 256).

In the process of internalization associated with the development of learners there are three stages that occur are:

a. Value transformation stage: This stage is a process conducted by educators in informing the good values and good size. At this stage only happens komuniasi verbal between educators and students.

b. Phase Transaction value: an educational stage with street value of two-way communication or interaction between students and educators reciprocal.

c. Transinternalisasi stage is much more profound stage of the transaction phase. At this stage not only be done with a verbal communication but also the mental attitude and personality. So at this stage communications play an active personality. (Muhaimin, 1996: 153)

From the definition of internalization associated with human development, that process of internalization must be in accordance with the developmental tasks. Internalization central merupkan personality change is a critical dimension to the changes of the human person in it has the meaning of personality to the response that occurs in the formation of human character.

2. Understanding the Values of Religion

Value is something abstract that can not be seen, touched, or felt and unlimited scope. Value is closely associated with notions and human activity are complex, making it difficult specified limit, because keabstrakannya that then arises assortment of understanding, including the following:

a. Value is a set of beliefs or feelings that is believed to be an identity which gives a special pattern on the pattern of thought, feeling, association or behavior. (Darajat, 
1992: 60)

b. Value is a normative pattern, which determines the desired behavior for a system that has to do with the environment without differentiating the functions of the parts (Arifin, 1987: 141).

c. Value is a reference and confidence in making choices (Mulyana, 2004: 11).

d. Values are empirical quality that can not be defined, but can only be experienced and understood directly (Chatib, 1996: 61).

e. Value is something that is abstract, it is ideal, not a concrete object, not a fact, not only completely wrong issue which, according to empirical evidence, but rather a matter of appreciation that is desired, liked and disliked (Chatib, 1996: 61).

Some understanding of the value of the above can be understood that the value is an abstract, ideal, and on questions of confidence to be desired, and leave a pattern on the pattern of thoughts, feelings, and behaviors. Thus to trace a value must be through interpretation against another reality in the form of action, behavior, mindset and attitude of a person or group of people.

Value is the general idea of the people, who spoke about what is good or bad, expected or unexpected, coloring value the thoughts of someone who had become one and can not be released.

Thus the value can be defined as a property contained in something put in the position of a valuable and respectable namely that these properties manjadikan something is sought after and loved, well loved by one person or group of people, for example it is nasab for respectable people have high value, knowledge for the scholars' high value and courage for the government has a value that is loved and so forth.

The religious sense by Tholhah Hasan (1986: 57) is the underlying orientation of the sins and virtues, halal and haram.

And understanding of Islam is a religion whose teachings sourced to the revelation of Allah. conveyed to mankind through Prophet Muhammad. For the welfare of mankind in the world and in the hereafter (Salih, 1976: 115).

So understanding the value of Islam in the discussion of this study is an effort to develop the knowledge and potential of the basic problems in the form of teaching that is sourced to the revelation of God which includes faith, minds, morals and charity to the orientation of merit and sin, so that Islamic teachings are can penetrate into the human self as a guide in life (Department of Education, 1990: 414).

Various religious values according to Nurcholish Madjid (2000: 98-100), there are some religious values that should be instilled in children and educational activities where this is the core of religious education. Among the basic values are: Faith, Islam, Ihsan, Taqwa, Ikhlas, resignation, Gratitude, Patience.

3. The Internalization Process of Islamic Religious Values

There are several processes to internalize religious values in students, namely: (Majid, 2000: 112-115)

a. Indoctrination approach, which is an approach used by the lecturer / educator with a view to mendoktrinkan or embed the learning material with force elements to be controlled by the student. Things that can be done by the lecturers in this approach is divided into three, namely:

1) Doing brainwashing, ie lecturers begin instilling values education with the values established in the person of the student to be confused.

2) Planting fanaticism, the lecturer instill new ideas or values that are completely in 
accordance with the values of Islam.

3) Planting doctrine, namely lecturers introduce the value of truth that must be accepted without questioning the student.

b. Approach to moral reasoning, which is an approach used lecturers to present materials related to the moral through logical are reasons to make the right choice. Things that can be done by the lecturers in this approach are:

1) Presentation of the moral dilemma is: students are faced with moral issues that are contradictory.

2) The division of the discussion groups are: students are divided into small groups for discussion.

3) Class discussion, small group discussion results brought into class discussions to obtain student rationale to take that into consideration and moral decisions.

4) Selection value is selected, ie that all students can make the selection according to the level of moral development as the basis of moral decision making and can make the selection of the appropriate value of the selected alternatives proposed.

c. Concequence forecasting approach: that is the approach used lecturers with a view to encourage students to find the possible consequences arising out of an act. Things that can be done lecturer in this case is

1) Presentation of cases of moral values, the students were given a case of moral values in society.

2) Asking questions, students are led to discover the value of the guide questions ranging from simple level questions to the high level questions.

3) Comparison of value that occurs with the supposed

4) Predict the consequences, students were told to predict due to happening of the selection and implementation of a value.

d. Value classification approach, which is an approach used to encourage student lecturers find an act that contains the elements of the value (both positive and negative) and will be found to the values that should be done. Things that can be done lecturer in this approach are:

1) Helping students to find and categorize the kinds of values

2) The process of setting goals, express their feelings, explore and clarify values

3) Planning for action

4) Implement the action according to the decision of values taken with models that can be developed through moralizing, planting moral directly with scrutiny, laisez faire, the child is given the freedom of the way the practice of selection of value unattended, modeling planting value by providing examples to be emulated.

e. Ibrah and amtsal approach, ie an approach used by the faculty in presenting the material with the intention of students can find stories and parables in an event, either already happening or not happening. Things that can be done lecturers, among others,

1) Invites students to discover through reading text or viewing media on a story and parable.

2) Asked the students to tell the story of an event, and find parables those who are in the story of the event.

3) Presenting some of the story of an event to discuss and find the parable as a result of the story.

4. Religious Character Education

Etymologically, the term comes from the Latin character "character", which means it 
can mean disposition, character, psychological traits, character, personality and character. The term character is also taken from the Latin kharakter, kharesian and xharaz meaningful tool for marking, to Engrave and pointed stake. (Wyne in Musfah, 2011: 127)

In English, the character is translated into a character derived from the Greek "charassein" which means to Engrave (Sahlan, 2012: 25). The word "to Engrave" can be translated sculpture, painting, carving, or scratch.

Characters are basic values that build one's personal, well-formed because of the influence of heredity and environmental influences, which distinguishes it from other people, as well as manifested in attitudes and behavior in everyday life (Samani, 2011: 43). While the character is a person who can respond to any situation morally and manifested in the form of concrete actions through good behavior.

Character education is a system of cultivation of character values to the school community, which includes knowledge, awareness or volition, and actions to implement these values (Sudrajat, 2010).

Character education is a system of value investment good character to all those involved and as a school community that has the knowledge, awareness, and actions to implement these values (Azzet, 2011: 36)

While character education in educational institutions as learning that led to the strengthening and development of the behavior of students as a whole are based on a value that is referenced by the institution. And the goal of character education in educational institutions are:

1) Strengthen and develop the values of life that are important and need to be personality or ownership typical learners as values developed.

2) Correcting the behavior of learners who did not correspond with the values developed by the school.

3) Building a harmonious connection to family and community in educational responsibilities portray the characters together (Kesuma, 2011: 5).

According to Suyanto, the noble universal values are nine characters to be the goal of character education. Nine characters that are:

1) Love of God and all His creation

2) Independence and responsibility

3) Honesty / trustworthy

4) Respectful and polite

5) Generous, helpful, and cooperation

6) Confident and hardworking

7) Leadership and justice

8) Kind and humble

9) Tolerance, peace, and unity (Azzet, 2011: 36)

The approach in the implementation of character education, the cultivation approach values (inculcation approach). Planting approach values (inculcation approach) is an approach that emphasizes the cultivation of social values in student self (Samani, 107).

In this approach, the method used in the learning process, among others, exemplary, positive and negative reinforcement, stimulation, play a role, and others.

In character education, as well as any concept of an educational character, if a lecturer is not precedent in the professor's behaving can not serve as a role model in developing and educating students. Therefore a teacher should be suspended taudalan for learners, and this will make it easier to build the character of a learner when lecturers can be a role model and an example for the students and facilitate in improving an educational institution. 
From the foregoing it is said that all menyangkup character education attitudes, morals, behavior, actions undertaken daily making temperament did not deviate from the learning that has been acquired by learners and guide the student life.

The word is the religious basis of religion derived from foreign languages religion as a form of a noun that means the religion or belief of the existence of something natural power above the human. While religious derived from the religious meaning of religious properties inherent in a person. Religious as one of the characters described by Suparlan value as submissive attitude and behavior in carrying out the teachings of religious beliefs, tolerant implementation of the practice of other religions, and live in harmony with other faiths. Religious character is urgently needed by the students in the face of changing times, in this case the students are expected to have and behave with good and bad measure based on the provisions and statutes of religion (2011).

In character education, morals became the first orientation in the formation of the student's character. In essence every human being has the attitude to make good behavior or vice versa. Humans have the potential from birth to choose, but menjadikanya is about to have the effect of positive character or not (Zubaedi, 2011: 66).

Thus, when teaching character education provided through religious aspects or based on religion, it will form a good combination with no values opposing or contradictory. This is because religion is a source of value in establishing character education learning (MONE, 2010: 67).

5. Internalization of Islamic religious values in shaping the religious character of Students

In general, the internalization of the values of the Islamic religion is one way of human mental shape to have personal moral, good morals, and morals that aims to foster mental and personality add faith to students. Internalization of religious values that give rise to faith, honesty, respect, courtesy, conduct, and character, is a good way to develop the mental attitude and personality of the students in particular and mankind in general, all of which should be based on the values of religion, especially religion Islam in accordance with the guidance of the Qur'an and As- sunnah.

Among the programs implemented to internalize the values of Islam are:

a. Reading Al-Qur'an and Its' translate every start lectures. This allows them to understand the verses of the Koran that they can implement in their daily lives.

b. Students are required to keep a journal of worship that will record their religious activities during one semester. Religious activities they do are expected to make the values of Islam can be internalized in their lives so that the religious character can be formed and embodied in Islamic morality.

c. Students are required to attend the program SCIENCE (Qur'an Intensive Study) that the learning program to read and write the Koran that will train students' ability in reading the Koran. Intimacy and closeness with the Qur'an which is the Muslim holy book, the student is expected to make the Qur'an as a guide to life so that the values of character and noble character can manifest in everyday behavior.

At the stage of internalization, there are academic and nonakademik realm, in the realm of academic lecturers using methods lectures, discussion, assignments, problem solving, discussions, demonstrations, simulations, and reference equation. In the realm of nonakademik, student organizations hold regular review, training and competitions on the theme of Islamic.

Enabling and inhibiting factors in the formation of a religious character in V UNM Campus Parepare is: 
a. Supporting factors:

1) Factors from the inside. The psychological factor in the students themselves can support the implementation process of internalization, because when the soul was happy to do an activity that it can easily get into the activities of student life. Thus it is necessary habituation continuously accompanied by keteladan that the activities carried out not in vain.

2) External factors:

a) Family. Student family background is very influential in the formation of his personality, that parents familiarize provide religious values since childhood is helping students receive all the training activities to improve the character in the campus environment.

b) The competence of lecturers in teaching and to provide role models,

c) The facilities were very adequate for all student activities,

d) Public. Society is a supporting factor of the internalization of religious values as the community is where they socialize in her life. So when people place their social berkehidupan Islami and either not aware they would be well-Islamic and in accordance with the teachings of Islam.

b. Obstacle factor:

1) Inhibiting factors of the students are of themselves due to differences in character, and background is different. Thus, in the coaching process conducted by lecturers sometimes did not work well for their students who can not understand and can not do that with good coaching.

2) External factors, namely:

a) Family: The family is a major factor in influencing all the psychological and behavior of students because the family is the education process that was first performed. If the family does not support the program in which students on campus, then the process of internalization of religious values to improve the character of the students it will be worth it.

b) Campus environment can be obstacles in the process of internalization of religious values in shaping the character of the students. Suppose there are several lecturers who are still busy teaching prayers when the activity took place.

c) Media information is a requirement that could become an obstacle if one in wielding it. If not used properly it can affect the students into a negative thing.

d) Society: People are the limiting factor of the process of internalization of religious values as if they socialize without being able to sort out where the good from the bad.

\section{Conclusion}

The process of internalization of religious values carried in religious programs are: 1 . Reading the Qur'an every start lectures, 2. Make the Journal of Worship, 3. Following the SAINS program (Intensive study of the Qur'an). Enabling and inhibiting factors in the formation of a religious character in V UNM Campus Parepare is: a. The supporting factors: 1) factors from within the student psychologically support the implementation of internalization. 2) External factors: a) Family: family background of students, b) the competence of lecturers in teaching and to provide role models, c) facilities were insufficient for all student activities, d) Society as their place to socialize. b. Inhibiting factors: 1) the 
inhibiting factors of the students are of themselves due to differences in character, and background is different. 2) External factors, namely: a) Family: Family is the main factor that affects all the psychological and behavior of students. b) campus environment can be obstacles in the process of internalization of religious values in shaping the character of the students. c) Media information is a requirement that could become an obstacle if one of access. d) Society: People are the limiting factor of the process of internalization of religious values as if they socialize without being able to sort out where the good from the bad. c) Media information is a requirement that could become an obstacle if one of access. d) Society: People are the limiting factor of the process of internalization of religious values as if they socialize without being able to sort out where the good from the bad. c) Media information is a requirement that could become an obstacle if one of access. d) Society: People are the limiting factor of the process of internalization of religious values as if they socialize without being able to sort out where the good from the bad.

\section{Reference}

Atjeh, Abu Bakar. 1968. Mutiara Akhlak 1. Jakarta: Bulan Bintang.

Azzet, Akhmad Muhaimin. 2011. Urgensi Pendidikan Karakter di Indonesia. Yogyakarta:ArRuzz Media.

Basrowi dan Suwandi. 2008. Memahami Penelitian Kualitatif. Jakarta: Rineka Cipta. 2008.

Daradjat, Zakiyat. 1983. Kesehatan Mental. Jakarta: Gunung Agung.

Departemen Agama RI. 2007. Al Qur'an dan Terjemahnya. Bandung: CV Penerbit Diponegoro.

Departemen Pendidikan dan Kebudayaan. 1990. Kamus Besar Bahasa Indonesia. Jakarta : Balai Pustaka.

Hadi, Sutrisno. 1993. Metodologi Riset. Yogyakarta: Andi Offset.

Majid, Abdul dan Dian Andayani. 2011. Pendidikan Karakter Perspektif Islam. Bandung: PT Remaja Rosdakarya.

Moleong, Lexy J. 2007. Metode Penelitian Kualitatif. Bandung : Rosda Karya. 2007.

Muchlas, Samani. dkk. 2011. Pendidikan Karakter. Bandung: PT Remaja Rosdakarya.

Muhaimin. 2005. Pengembangan Kurikulum PAI di Sekolah Madrasah dan Perguruan Tinggi. Jakarta: Raja Grafindo Persada.

Nawawi, Hadari. 2000. Metode Penelitian Bidang Sosial. Yogyakarta: Gadjah Mada University Pers.

Nazir, M. 1988. Metode Penelitian. Jakarta : Ghalia Indonesia.

Rahmat, Jalaluddin. 1997. Psikologi Agama. Jakarta: PT Grafindo Persada.

Samani, Muchlas dan Hariyanto. 2011. Konsep Dan Model Pendidikan Karakter. Bandung: PT Remaja Rosdakarya Offset.

Sugiono. Memahami Penelitian Kualitatif. Bandung : CV. Alfabeta.

Sugiyono. 2010. Metode Penelitian Pendidikan: Pendekatan Kuantitatif, Kualitatif, dan R\&D. 
Bandung: Alfabeta.

Surahmad, Winarno. 1992. Pengantar Penelitian Ilmiah Dasar Metode dan Teknik. Bandung: Tarsito.

Syah, Muhibin. 2005. Psikologi Pendidikan dengan Pendekatan Baru. Cet V. Bandung : Remaja Rosdakarya. 